\title{
Analisis gambaran radiologis suspek ameloblastoma tipe solid pada radiograf CBCT 3D
}

\author{
Farina Pramanik ${ }^{*}$, Lusi Epsilawati ${ }^{1}$ Yurika Ambar Lita', Erna Herawati ${ }^{2}$
}

\begin{abstract}
Objectives: The aim of this case report is to provide further information on the radiological features of a solid type ameloblastoma suspected on a $3 D$ CBCT radiograph.

Case Report: A patient came referred by a dentist for $C B C T$ 3D radiography with suspected clinical diagnosis of a maxillary anterior dentigerous cyst. The results of the $C B C T 3 D$ radiographic examination showed a radiointermediate with a clear border on the anterior maxilla and in the right maxillary sinus accompanied by the impact of two supernumerary teeth. Radiological features of ameloblastoma generally show a multilocular

radiolucent picture and have a radiopaque septa bone internal structure such as a soap bubble appearance or honey combed appearance. This case showed a clearly demarcated radiointermediate image because a solid type ameloblastoma contains tissue that is histologically formed from cells hat are follicular or plexiform and derived from the results of a degenerative process at the center of the Langerhans islands.

Conclusion: Radiographic examination with high modality such as CBCT $3 D$ is very important in helping to establish a diagnosis, especially for cases that sometimes show differences in the radiographs.
\end{abstract}

Keywords: Ameloblastoma solid type, radiography, CBCT 3D

Cite this article: Pramanik F, Epsilawati L, Lita YA, Herawati E. Analisis gambaran radiologis suspek ameloblastoma tipe solid pada radiograf CBCT 3D. Jurnal Radiologi Dentomaksilofasial Indonesia 2019;3(2)1520. https://doi.org/10.32793/jrdi.v3i2.492

\section{PENDAHULUAN}

Ameloblastoma adalah tumor yang persisten dan invasif secara lokal; bersifat agresif namun karakteristik pertumbuhannya jinak. Ameloblastoma berasal dari sisa-sisa dental lamina dan organ gigi (epitel odontogenik), sehingga masuk klasifikasi tumor jinak odontogenik. ${ }^{1,2}$ Rosai mengklasifikasikan tumor odontogen menjadi 3 bagian besar yaitu tumor odontogenik jinak, borderline, dan ganas. Ameloblastoma rahang termasuk dalam tumor odontogen yang borderline., Etiologi ameloblastoma dapat disebabkan oleh faktor iritasi non spesifik seperti ekstraksi, karies, trauma, infeksi, inflamasi atau erupsi gigi; kelainan defisit nutrisional dan patogenesis viral. $^{2}$ Sekitar $17 \%$ ameloblastoma berhubungan dengan gigi impaksi atau kista dentigerous. $^{3}$

Ameloblastoma bersifat jinak, pertumbuhan "Correspondence to: Farina Pramanik

凤farina.pramanik@fkg.unpad.ac.id mobilitas. Ketika tumor membesar, palpasi dapat menimbulkan hard sensation pada tulang keras atau krepitasi karena tulang menipis. Jika lesi menghancurkan tulang, pembengkakan mungkin disertai firm atau fluktuasi. Tumor ini dapat menyebabkan ekspansi tulang dan kadang-kadang erosi pada pelat kortikal yang berdekatan dengan invasi berikutnya pada jaringan lunak yang berdekatan. $^{1,7}$

Prinsip terapi ameloblastoma adalah pengambilan tumor secara keseluruhan. Banyak klinisi yang lebih memilih terapi radikal karena sifat kekambuhannya. Perawatan dengan metode radikal dapat menurunkan tingkat kekambuhannya. ${ }^{5,7}$ Ameloblastoma tipe solid terkadang memperlihatkan gambaran radiologis yang berbeda pada berbagai pemeriksaan radiogafi sehingga sulit diidentifikasi. Untuk itu untuk menegakan diagnosis yang tepat baiknya melakukan beberapa teknik radiografi. Untuk kasus seperti ini diperlukan modalitas tinggi sehingga dapat memberikan gambaran yang lebih akurat yaitu radiografi CBCT 3D. ${ }^{1}$

Tujuan laporan kasus ini adalah untuk memberikan informasi lebih lanjut mengenai gambaran radiologis suspek ameloblastoma tipe solid pada radiograf CBCT 3D. 


\section{LAPORAN KASUS}

Seorang pasien laki-laki berusia 27 tahun datang ke Instalasi Radiologi Kedokteran Gigi RSGM Unpad untuk dilakukan CBCT-3D. Berdasarkan hasil anamnesa, keluhan pasien adalah terlihat bengkak di daerah langit-langit rahang atas lebih dari 1 tahun yang lalu, bengkak meluas ke pipi sejak 1-2 bulan yang lalu. Bengkak tidak terasa nyeri. Belum pernah diobati dan periksa ke dokter. Tidak ada riwayat demam. Pasien belum mengkonsumsi obat apapun. Dokter pengirim konsul menyatakan bahwa pasien suspek kista dentigerous anterior RA. Riwayat pasien terdahulu yaitu pernah memiliki tahi lalat yang banyak dan jika tergesek (misal oleh handuk) maka akan berdarah. Pasien 11 tahun yang lalu pernah menjalani operasi tumor di lutut. Tumor tersebut ada sejak lahir.

Hasil pemeriksaan klinis secara umum tidak ditemukan suatu kelainan (Tabel 1). Keadaan ekstraoral menunjukkan wajah asimetris ringan, pipi kanan dekat hidung terlihat lebih besar, kulit di sekeliling lesi terlihat normal, dengan palpasi: konsistensi keras, batas jelas, nyeri ringan (Gambar 1). Pada pemeriksaan intraoral ditemukan pmbengkakan pada regio anterior rahang atas, 16 s.d 22 dengan mukobukofold terangkat, warna jaringan pada lesi sama dengan warna jaringan sehat disekitarnya. Palpasi; konsistensi keras, nyeri ringan. Pembengkakan ringan pada palatum

Tabel 1. Hasil pemeriksaan klinis secara umum

\begin{tabular}{ll}
\hline Keadaan Umum & Baik, status gizi: baik, status nyeri: nyeri ringan \\
\hline Kesadaran & Compos Mentis \\
\hline Vital Sign & Dalam batas normal \\
\hline KGB & Limphadenopathy submandibula sinistra $(+)$ teraba \\
\hline Status Neurologis & Defek N.V3 (-), defisit neurologis fokal $(-)$ \\
\hline
\end{tabular}

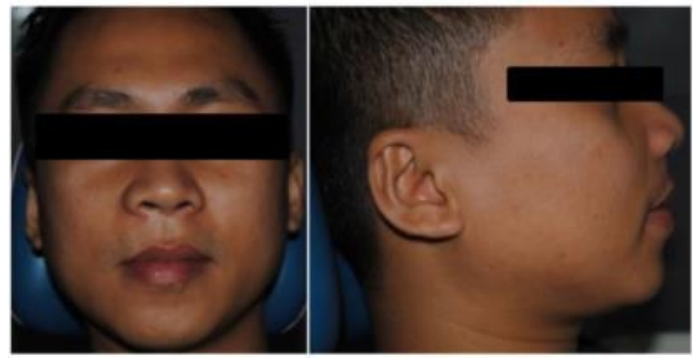

Gambar 1. Tampakan klinis ekstraoral pasien suspek ameloblastoma tipe solid

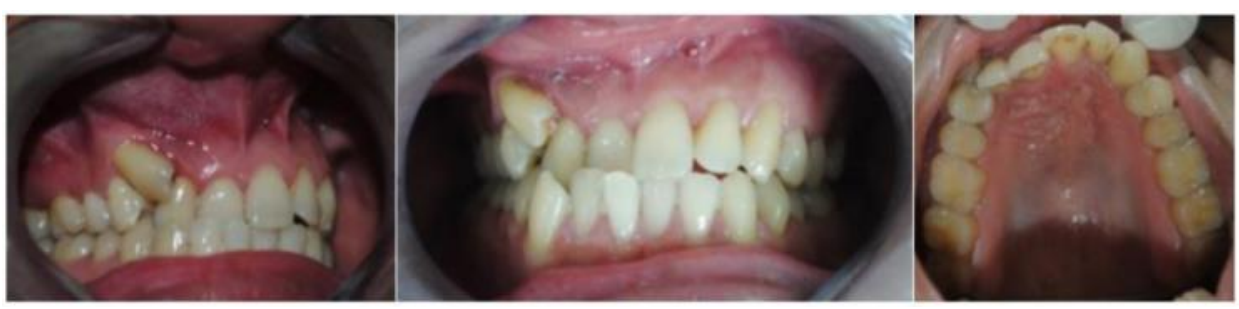

Gambar 2. Tampakan klinis intraoral pasien suspek ameloblastoma tipe solid

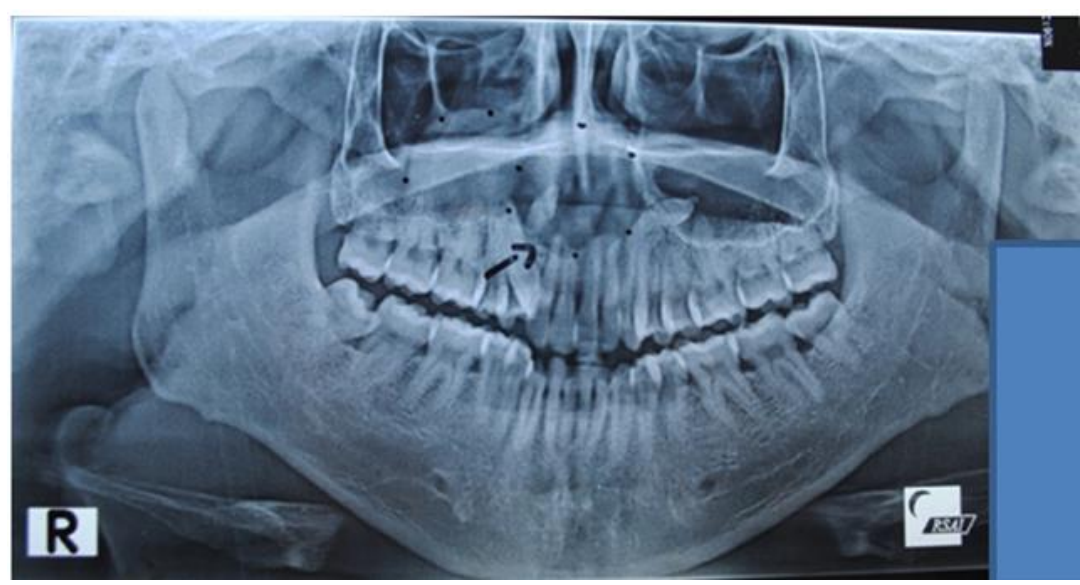

Gambar 3. Radiograf panoramik pasien suspek ameloblastoma tipe solid 
Tabel 2. Hasil interpretasi radiograf panoramik

\begin{tabular}{ll}
\hline Area 1 (Gigi-Geligi) & \\
Missing Teeth/Agenesia & Tidak ada \\
Persistensi & Tidak ada \\
Impaksi & 48 \\
Kondisi Mahkota & Radiolusen setengah mahkota gigi 32, 41, 43 \\
Kondisi Akar & Dalam batas normal \\
Kondisi Alveolar Crest, Furkasi & Penurunan puncak tulang alveolar posterior kanan \& anterior RA; seluruh RB \\
Kondisi Periapikal & Dalam batas normal \\
\hline
\end{tabular}

Area 2 (Maksila-Sinus-Nasal)

Gambaran radioopak menyerupai gigi supernumerary pada apikal $13 \mathrm{dg}$ posisi inverted, gigi supernumerry pada apikal $23 \mathrm{dg}$ posis $\mathrm{i}$ inverted dg mahkota superimposed dg sinus maksilaris sinistra.

- Lokasi: di anterior rahang atas meluas hingga kavum nasal dan sinus maksilaris kanan

- Margin/batas: well-defined tanpa kortikasi

- Ukuran: diameter $\pm 5 \mathrm{~mm}$ di cavum nasi, $7 \mathrm{~mm}$ di sinus maksilaris dextra

- Struktur internal: tamoak bayangan radiolusen pada anterior maksila meluas ke cavum nasii, terlihat gambaran radiointermediet pada sinus maksilaris

- Efek jaringan sekitar: terjadi perluas dan lesi hingga menyebabkan perforasi dasar sinus maksilaris kanan, cavun nassi dan palatum

Area 3 (Mandibula)

Dalam batas norma

\begin{tabular}{ll}
\hline Area 4 (TMJ) & \\
$\begin{array}{ll}\text { Bentuk Kondilus-Fossa-Eminensia } & \text { Asimetris: Flattening HOC dextra, oval HOC sinistra } \\
\text { Posisi Kondilus } & \text { Asimetris; HOC sinistra lebih ke anterior }\end{array}$ \\
\hline
\end{tabular}

Area 5 (Ramus-OS Vertebrae)
Dalam batas normal

Dalam batas normal

Kesan

Terdapat kelainan pada area gigi, maksila, nasal, sinus, TMJ

\begin{tabular}{ll}
\hline Suspek Radiologis & Pulpitis gigi $32,41,43$ \\
- Impaksi kelas $1 \mathrm{~A}$ mesioversi 48 \\
- Gigi supernumerary regio apikal 13 dan 23 \\
- Ameloblastoma tipe solid regio anterior maksila meluas ke nasal dan sinus maksilaris dextra
\end{tabular}

anterior dengan palpasi konsistensi keras, tidak nyeri (Gambar 2). Hasil interpretasi atau pembacaan radiograf baik dari radiograf panoramik (Tabel 2) maupun CBCT terlampir (Tabel 3). Dari hasil pemeriksaan radiograf dapat disimpulkan bahwa pasien suspek ameloblastoma regio maksila anterior meluas ke nasal dan sinus maksilaris kanan.

\section{DISKUSI}

Kasus ini memperlihatkan dua buah gambaran radiografi yaitu 2 dimensi (panoramik) dan 3 dimensi (CBCT 3D). Pemeriksaan penunjang radiografi panoramik dilakukan atas dasar kebutuhan dari pemeriksaan klinis. Pemeriksaan radiografi $\mathrm{CBCT}$ 3D dilakukan karena hasil pemeriksaan radiografi panoramik masih memerlukan informasi lebih lanjut. Radiografi panoramik sudah cukup membantu dalam menggambarkan lesi yang terjadi pada rahang bawah, sedangkan pada rahang atas kadang-kadang masih diperlukan foto Waters dan oklusal, serta modalitas yang lebih tinggi seperti CBCT 3D, CBCT 3D menggunakan sinar dengan teknik Cone Beam dimana sinar berbentuk kerucut berputar mengelilingi kepala pasien dan rekontruksi volumetrik berbasis komputer dengan gambaran 3D mengambil gambar dengan sensor flat panel selama 5-40 detik, dosis $25-60 \mu \mathrm{sv}^{1}$

Kasus ini memperlihatkan bahwa pemeriksaan radiografi dengan modalitas yang lebih tinggi dapat memperlihatkan gambaran yang lebih akurat. Pemeriksaan beberapa teknik radiografi juga dapat memberikan gambaran yang lebih jelas sehingga diagnosis yang ditegakan lebih akurat. Ameloblastoma secara radiologis dapat berupa gambaran polikistik atau monokistik, dan secara histopatologi menunjukan gambaran yang berbedabeda, sehingga terkadang dibutuhkan lebih dari satu irisan untuk membuat diagnosa yang tepat. ${ }^{4,8}$

Neville mengelompokkan ameloblastoma atas 3 kategori berdasarkan perbedaan klinis radiologis, dimana masing-masing kategori memiliki pertimbangan terapi dan prognosis tersendiri yaitu : (1) tipe multilokuler (2) tipe unilokuler (3) tipe periferal atau ekstraosseous. Ameloblastoma tipe multilokular terjadi kira-kira $86 \%$ dari seluruh kasus, tipe unikistik terjadi sebanyak $13 \%$, dan tipe ekstraoseus sebanyak $1 \%{ }^{4,8,10,11}$

Menurut gambaran radiologis, ameloblastoma rahang dibagi dalam beberapa tipe: ${ }^{3,6,7}$

Monokistik, secara radiologis lesi ini terlihat terlihat sebagai daerah yang radiolusen pada sekeliling mahkota gigi molar ketiga mandibula yang tidak erupsi dengan tepi yang tegas. Gambaran lesi pada 

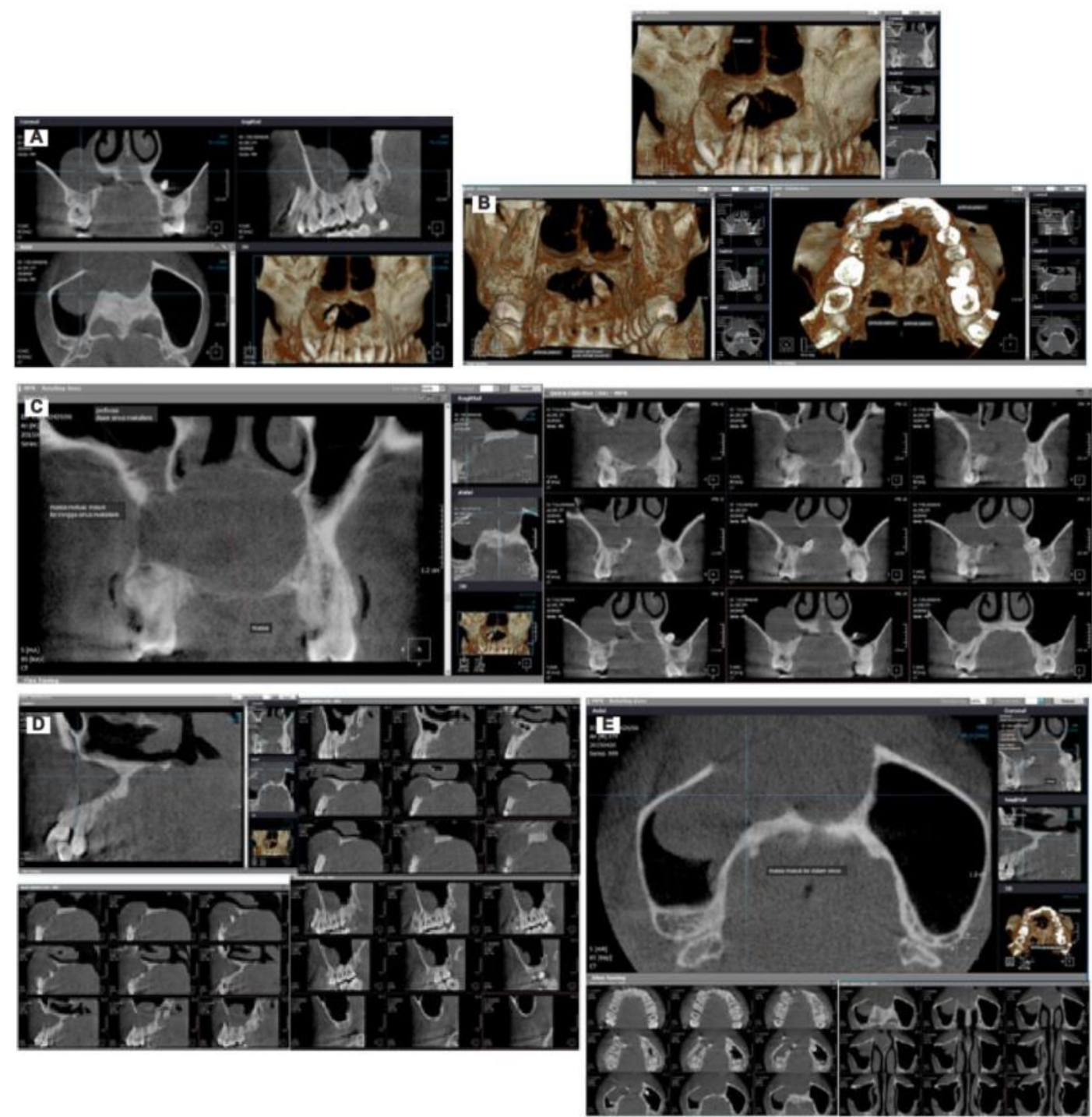

Gambar 4. Radiograf CBCT 3D pasien suspek ameloblastoma tipe solid. (A) MPR view. (B) 3D view area maksila anterior dari arah anterior, posterior dan inferior. (C) Coronal view dan slicing view dari arah anterior ke posterior. (D) Sagittal view dan slicing view. (E) Axial view \& slicing view dari arah anterior ke posterior

Tabel 2. Hasil interpretasi radiograf CBCT 3D

\section{D View}

Terlihat perforasi maksil anterior sd palatum dan cavum nasi, terlihat gigi supernumerary inverted pada region apical gigi 12

\section{Coronal View}

Terlihat gambaran radiointermediet pada maksila anterior meluas ke sinus maksilaris dextra dan cavum nasi. Perforasi dinding anterior sinus maksilaris dextra, dan dinding inferior cavum nasi. Terlihat gambaran radioopak menyerupai gigi supernumerary pada area inferior sinus maksilaris sinistra.

\section{Sagittal View}

Terlihat gambaran radiointermediet pada sinus maksilaris dextra bagian anterior, batas reguler

\section{Axial View}

Terlihat gambaran radiointermediet pada anterior maksila meluas ke sinus maksilaris dextra dengan perforasi dinding sinus maksilaris dextra bagian anterior an perforasi anterior maksila dan palatum.

Kesan

Massa solid di palatum yang meluas ke nasal dan sinus maksilaris dextra

\begin{tabular}{lll}
\hline Suspek Radiologis & Ameloblastoma tipe solid di regio maksila anterior disertai impaksi 2 gigi supernumerary di regio
\end{tabular} maksila anterior 
umumnya berbentuk unilokuler (Gambar 6A), lesi ini memiliki kecenderungan untuk tumbuh membesar dengan ekspansi ke arah bukal dan lingual serta terlihat adanya resorpsi akar.Terdapat perubahan letak posisi gigi dan kanalis mandibularis ${ }^{2,4,11,14}$; (2) Multikistik, lebih mudah dikenali, tetapi kadang-kadang gambarannya sangat berbeda. Gambaran radiologis yang khas adalah adanya lesi yang multilokuler dan di gambarkan sebagai gambaran busa sabun (soap bubble appearance) bila lokasi daerah radiolusen luas, atau gambaran sarang lebah (honeycomb appearance) bila lokasi daerah radiolusen kecil (Gambar 6B). Selain itu dapat terlihat adanya ekspansi kortikal ke arah bukal dan lingual, resorpsi akar gigi dan gambaran radiolusen pada gigi yang tidak erupsi ${ }^{15}$; (3) Peripheral, dikarenakan lesi berasal ekstraosseus, perubahan pada tulang jarang terlihat. Biasanya lesi akan terlihat superfisial pada tulang kortikal sebagai gambaran radiolusensi "cup shaped" dibawah tonjolan nodul sebagai akibat dari tekanan dari lesi pada tulang (Gambar 6C). Jika lesi terletak pada papila interdental, akan terlihat perenggangan pada gigi. ${ }^{16}$

Radiodiagnosis kasus ini adalah ameloblastoma tipe solid. Gambaran radiografi ameloblastoma tipe solid memiliki gambaran radiointermediet dan batas jelas. Ameloblastoma tipe solid bersasal dari hasil proses degeneratif pada pusat pulau2 langerhans. Menurut Fonseca (2000) ameloblastoma tipe solid terbentuk ketika focal kecil dari ameloblastoma berubah menjadi masa padat dan menetap menjadi bentuk yang solid . Secara histoligis berbentuk folicular atau pleksiform merupakan bentuk yang sering terjadi sedangakan bentuk achantomatous granular cell desmoplastik dan tipe basal sel merupakan bentuk yang jarang terjadi. Tampilan radiografis ameloblastoma conventional solid atau intraosseous sering berbentuk radiolusen multiokular dan mempunyai struktur internal tulang septa yang radioopak. Tampilan ini mempunyai gambaran soap bubble dan honeycombed. Biasanya terjadi ekspansi tulang kortikal bukal dan lingual serta dapat terjadi resopsi akar gigi tetangga. ${ }^{12,16}$

Pemeriksaan radiografi suatu jaringan akan memberikan gambaran radiointermediet. Gambaran unilokuler yang menyerupai ameloblastoma tipe kistik dapat pula terlihat pada ameloblastoma tipe solid dengan tepi berbentuk seperti kulit kerang (scalloping) yang tidak teratur. Gambaran khas radiografis lainnya adalah adanya

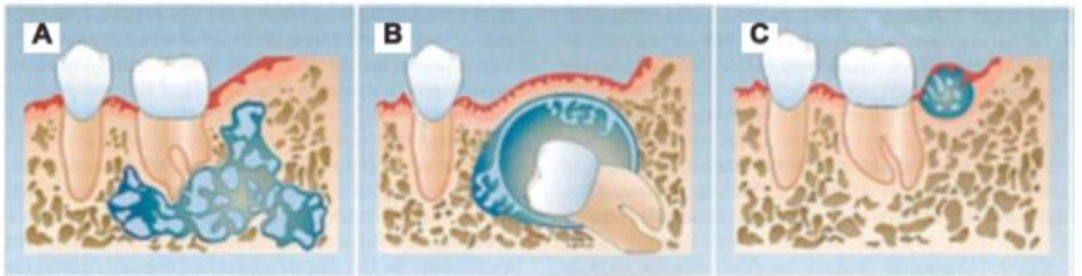

Gambar 5. Tiga subtipe klinis ameloblastoma, (A) multilokular, (B) unilokular, (C) periferal (ekstraosseous) ${ }^{9}$

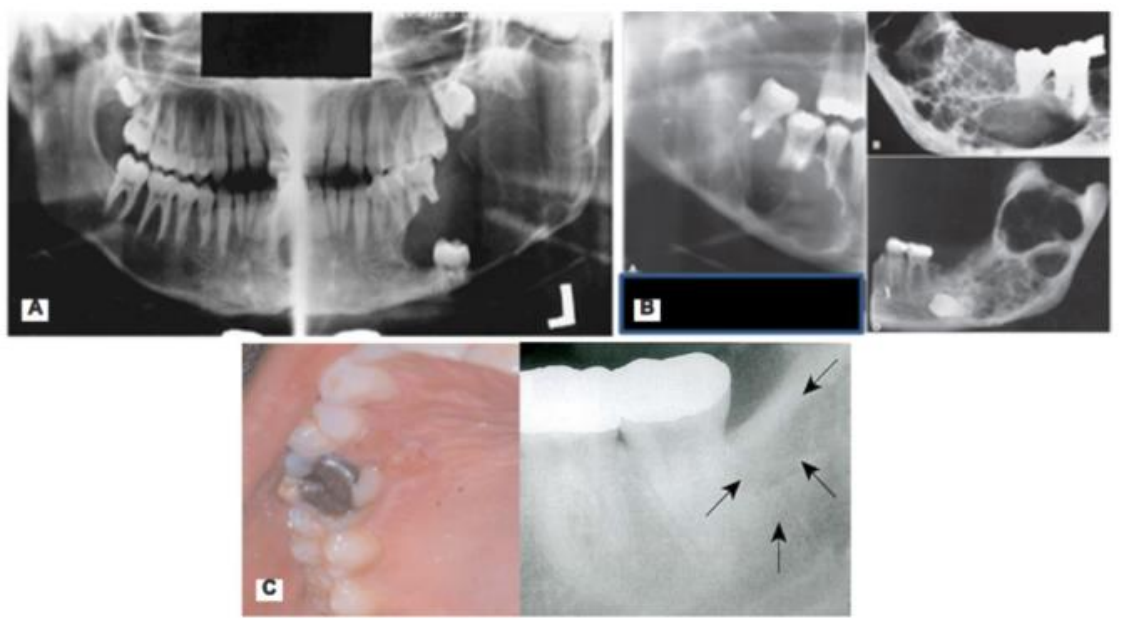

Gambar 6. Gambaran radiografi tiga subtype ameloblastoma, (A) unilokular, (B) multilokular, (C) periferal ${ }^{1,2,8,15}$

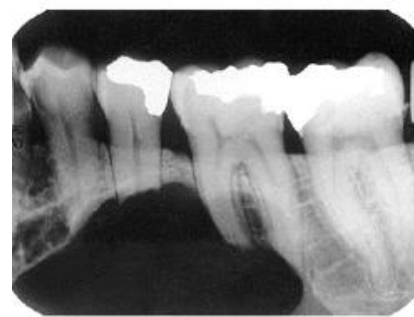

Gambar 7. Gambaran radiografi ameloblastoma dengan efek akar gigi premolar mengalami resorpsi ${ }^{1,16}$ 
bulging fenomena, kanalis mandibularis yang terdorong ke bawah dan perpindahan lokasi gigi. ${ }^{2}$ Gambaran radiografi yang paling sering ditemukan adalah lesi multilokular radiolusen dan memberikan gambaran radiografis seperti "soap bubble". Ukuran yang sebenarnya dari lesi ini sulit untuk ditentukan karena lesi ini tidak memiliki batas yang jelas dengan tulang normal. Resorpsi akar jarang terjad tetapi biasanya terlihat pada lesi yang berkembang cepat. ${ }^{8}$ Ameloblastoma pada uumnya berkaitan dengan gigi impaksi, dalam kasus ini terdapat gig impaksi dua buah gigi supernumerary.

Kasus ini terjadi pada pria, meskipun secara teoritis gambaran klinis ada kecenderungan sedikit untuk lesi ini terjadi pada pria. Sebagian besar pasien adalah antara 20 dan 50 tahun, dengan usia rata-rata di penemuan sekitar 40 tahun, meskipun mungkin ditemukan pada anak-anak ( 3 tahun) dan orang yang lebih tua dari 80 tahun. ${ }^{1}$ Kasus ini terjadi pada usia 27 tahun yang masuk kedalam usia mayoritas terjadinya ameloblastoma. ${ }^{14}$

Kebanyakan ameloblastoma (80\%) berkembang pada molar ramus mandibula, kemudian meluas ke daerah symphyseal. Kebanyakan lesi yang terjadi pada rahang atas berada di daerah molar ketiga dan meluas ke sinus maksilaris dan dasar hidung, ${ }^{1}$ hal ini dapat menyebabkan gangguan bicara dan menelan. ${ }^{3,7}$ Kasus ini terjadi pada anterior maksila dan terjadi perforasi maksila anterior, palatum anterior dan posterior serta sinus maksilaris dextra. Meskipun maksila anterior bukan lokasi maayoritas tetapi karakteristik perluasannya sesuai dengan jik terjadi di maksila anterior yaitu ke sinus maksilaris dan dasar hidung. Tumor yang tidak diobati dapat tumbuh sampai ukuran besar dan lebih banyak $d$ rahang atas, di mana ia dapat meluas ke struktur vital dan mencapai ke dasar tengkorak. Tumor yang berkembang di rahang atas dapat meluas ke sinus paranasal, orbit, nasofaring, atau struktur vital di dasar tengkorak. ${ }^{1}$

Gejala klinis yang terjadi pada kasus ini sesua denga gejala klinis yang mayoritas terjadi pada ameloblastoma yaitu ameloblastoma bersifat jinak, pertumbuhan lambat, bersifat invasi lokal dan tidak menimbulkan rasa nyeri. Warnanya sama dengan jaringan sekitarnya,jarang menimbulkan keluhan nyeri kecuali bila lesinya terinfeksi atau mendesak syaraf.Bila telah membesar sekali dapat menimbulkan deformitas wajah Umumnya ameloblastoma rahang tidak memberikan gambaran klinis yang spesifik. Ameloblastoma tipe solid memiliki ciri benjolan yang terbentuk konsistensinya keras. Ameloblastoma dapat memiliki benjolan dengan konsistensi keras atau lunak tergantung dari tipenya yaitu tipe solid atau tipe kistik. Kadang-kadang terdapat campuran antara kedua tipe tersebut. ${ }^{3,7,16}$

Ameloblastoma unilocular yang kecil terletak di sekitar mahkota gigi yang tidak erupsi sering tidak bisa dibedakan dari kista dentigerous. Karena penampilan dari tulang internal yang septa penting untuk identifikasi, jenis lesi yang juga memiliki septa internal seperti keratocyst odontogenik, granuloma sel raksasa, odontogenik myxoma, dan perkerasan fibroma, mungkin memiliki penampilan yang sama.
Gambaran radiointermediet terlihat pada Pesudocyst dan sering berada di dalam sinus maksilaris sama dengan yang terjadi pada kasus ini, ada umumnya di dasar sinus, tidak memiliki kortikal, halus, berbentuk kubah, massa radiopak mosty sessile. Retention pseudocyst berbentuk kubah tetapi tidak memiliki garis marginal tipis radiopak mewakili batas kortikal yang merupakan karakteristik kista atau neoplasma. Neoplasma jinak juga mirip retention pseudocyst. Jika neoplasma jinak berasal dari luar sinus, mereka akan terpisah dari ruang sinus dengan batas radiopak, mirip dengan kista odontogenik. ${ }^{1,14,16}$

\section{SIMPULAN}

Pemeriksaan radiografi dengan modalitas yang tinggi seperti $\mathrm{CBCT} 3 \mathrm{D}$ sangat penting dalam membantu menegakan diagnosis terutama untuk kasus yang terkadang memperlihatkan perbedaan pada gambaran radiografinya.

\section{DAFTAR PUSTAKA}

1. White S.C dan Pharoah, M.J. Oral Radiology Principles and Interpretation, 7th edition. Mosby Co: St. Louis; 2014

2. Andrew C. McClary, Robert B. West, Ashley C. McClary, et all. Ameloblastoma: a clinical review and trends in management. J Eur Arch Otorhinolaryngol. 2015

3. Rosai J. Surgical Pathology, 8th ed, St.Loius,Mosby; 1996.

4. Vohra FA, Hussain M, M Mudassir M.S. Ameloblatoma and their Management : A review. Journal of Surgery Pakistan (International). $2009: 14$ (3) : 136-142

5. Neville, BW et al. Oral and Maxillofacial Pathology, WB Saunders Co,Philadhelphia; 2002. 511-537.

6. Gümgüm, asak Hosgören. Clinical and Radiologic Behaviour of Ameloblastoma in 4 Cases. J Can Dent Assoc 2005; 71(7):4814

7. Giovana M.F, Cassiano F W N, Lélia Batista, Márcia Cristina, Leão Pereira Pinto. Solid ameloblastomas - Retrospective clinical and histopathologic study of 54 cases. Braz J Otorhinolaryngol.2010;76(2):172-7

8. Doenja Hertog 1, Elisabeth Bloemena 1, Irene H A Aartman 2, Isaäc van-der-Waal. Histopathology of ameloblastoma of the jaws; some critical observations based on a 4 . years single institution experience. Journal section: Oral Medicine and Pathology.2012: 1;17 (1):e76-82.

9. Robbins and Cotran. Pathologic Basic of Disease 5th edition. New York: WB Saunders. 2008.

10. Shafer WG, Hine MK, Levy BM. A textbook of oral pathology.4th ed. Philadelphia: WB Saunders; 1983. p. 27685 .

11. Cumming C.W. et al. editor,Schuller, Otolaryngology- Head and Neck Surgery, 2nded.,St. Louis,Mosby. 1993. 1430-1435

12. Sciuba, Robert \& Robinson's Head and Neck Pathology; Atlas for Histologis and Pathologic Disease. Philadelphia: Lipincott and Williams. 2004. 46-52

13. Sapp, JP et al. Contemporary Oral and Maxillofacial Pathology, 2nd ed, Mosby, St Louis. 2004.136-143

14. Hertog D, Bloemena E, Aartman I.H.A, Van Der Wal, I. Histopathology of ameloblastoma of the jaws; some critical observations based on a 40 years single institution experience. Journal section: Oral Medicine and Pathology.Publication Types: Research. Med Oral Patol Oral Cir Bucal. 2012 Jan 1;17 (1):e76-82.

15. Swati Deshmane, Ambika Arora, Deepa Das, Akansha Chaphekar, Komal Khot. Follicular Ameloblastoma: A Case Report. International Journal of Oral Health and Medical Research.2016: 3(4): 56-9

16. Di Cosola M, Turco M, Bizzoca G, Tavoulari K, Capodiferro S, Escudero-Castaño N, Lo Muzio L. Ameloblastoma of the jaw and maxillary bone: clinical study and report of our experience. J Avances En Odontoestomalogia.2007: 3(6): 367373 